\title{
IN-VITRO STUDY OF ANTIOXIDANT ACTIVITIES FROM ETHANOL EXTRACTS OF AKAR KUNING (Arcangelisia flava)
}

\author{
${ }^{1 *}$ Suratno, ${ }^{2}$ Muhammad Ikhwan Rizki, $\&{ }^{3}$ Mohammad Rizki Fadhil Pratama \\ ${ }^{1}$ Department of Medical Laboratory Technology, Faculty of Health Science, \\ Universitas Muhammadiyah Palangkaraya \\ 2Pharmacist Study Program, Faculty of Mathematics and Natural Sciences, \\ Universitas Lambung Mangkurat \\ ${ }^{3}$ Department of Pharmacy, Faculty of Health Science, \\ Universitas Muhammadiyah Palangkaraya \\ e-mail: nono.suratno89@yahoo.com
}

\begin{abstract}
ABSTRAK
Penelitian ini bertujuan untuk mengetahui aktivitas antioksidan dari ekstrak batang Akar Kuning (Arcangelisia flava) dari Kalimantan Tengah menggunakan metode 1,1-difenil-2pikrillhidrazil (DPPH). Penelitian ini meliputi ekstraksi simplisia dan uji aktivitas antioksidan dengan metode DPPH. Berdasarkan analisis aktivitas antioksidan pada ekstrak etanol dari batang tanaman akar kuning diperoleh nilai $I_{50}$ sebesar $136,81 \mathrm{ppm}$. Nilai $I_{50}$ ini menunjukkan kekuatan antioksidan yang terkandung dalam batang tanaman akar kuning termasuk dalam kategori sedang. Penelitian lebih lanjut tentang aktivitas antioksidan pada fraksi batang kuning perlu dilakukan untuk menentukan komposisi senyawa antioksidan dalam setiap pelarut.
\end{abstract}

Kata kunci: Arcangelisia flava, antioksidan, DPPH

\begin{abstract}
This study aims to determine the antioxidant activity of akar kuning (Arcangelisia flava) stem extract from Central Kalimantan using 1,1-diphenyl-2-picrylhydrazyl (DPPH) method. This research includes extraction of simplicia and test of antioxidant activity by DPPH method. Based on the analysis of antioxidant activity on ethanol extract from yellow root plant stem $I C_{50}$ values of $136.81 \mathrm{ppm}$ were obtained. This $\mathrm{IC}_{50}$ value indicates the antioxidant strength of the yellow root plant stems including in the moderate category. Further research on antioxidant activity in the fraction of akar kuning stems needs to be done to determine the composition of the antioxidant compounds in each solvent.
\end{abstract}

Keywords: Arcangelisia flava, antioxidant, DPPH 


\section{INTRODUCTION}

Akar kuning or kayu kuning (Arcangelisia flava) is a medicinal plant from Central Kalimantan which is known to have antifungal activity, especially from the stem which containing berberine ${ }^{1,2,3}$. Akar kuning grow a lot in forest areas in Kalimantan, including in Central Kalimantan. For the Dayak tribe, akar kuning is used to treat various diseases such as phlegm, scabies, ringworm, malaria, fever, and several bacterial infections $^{2,4}$. Previous studies showed that the antimicrobial activity of the yellow root stem was predominantly influenced by the presence of berberine in extracts and polar fractions ${ }^{2}$.

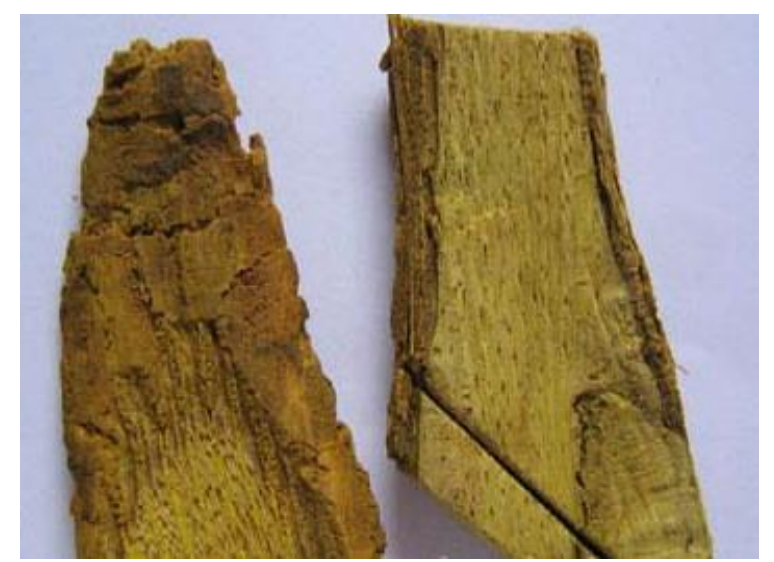

Figure 1. Stem of akar kuning ${ }^{1}$

In other regions in Indonesia such as in Sumatra, akar kuning are also used to treat jaundice and diarrhea. Currently, the use of akar kuning in new communities is limited to the use of a decoction of water to drink ${ }^{1}$. Besides containing berberine, akar kuning is also known to provide various other secondary metabolites such as saponins, flavonoids, polyphenols, glycosides, and other alkaloids. One of the similarities in the features of some of these metabolites is that almost all have the potential to be used as antioxidant compounds ${ }^{5}$.

Antioxidant compounds from natural ingredients consist of various groups of compounds such as tocopherol, lecithin, phosphatide, sesamol, gossypol, carotene, tannic acid, gallic acid, ferulic acid, and quercetin. While for synthetic antioxidants are antioxidants obtained from the synthesis of chemical compounds, such as butyl hydroxy anisole (BHA), butyl hydroxy toluene (BHT), terbutyl hydroxyquinone (TBHQ), diphenilpicrylhydrazil (DPPH), and dinitrophenylhydrazine $(\mathrm{DNPH})^{6,7}$. These antioxidant compounds are needed by the body to deal with oxidative stress, which can trigger various diseases such as cancer, diabetes mellitus, and atherosclerosis ${ }^{8}$.

Various antioxidant compounds can be found in the form of secondary metabolites of medicinal plants, where plants are known as the most significant source for the discovery of new antioxidant compounds ${ }^{9}$. These secondary metabolites often have various uses, such as being used as traditional medicine to treat multiple diseases in humans including diseases caused by oxidation processes at the cellular level. The cellular oxidation process is closely related to various degenerative diseases, including those related to the aging ${ }^{5}$. 
Suratno, Muhammad Ikhwan Rizki, and Mohammad Rizki Fadhil Pratama

Determination of antioxidants contained in a plant sample can be done through several methods. One standard test used to analyze the content, and antioxidant concentration is to use a technique based on the reduction of DPPH reagent. DPPH is a free radical that is stable at room temperature, which produces a purple solution in methanol ${ }^{10}$.

\section{METHOD}

\section{Collection of akar kuning stems}

Akar kuning stems are collected and separated from the dirt that may stick and other impurities. The portion of the stem that has been collected is then transferred into a dry and clean storage container so that it is not overgrown with mold.

\section{Simplicia Preparation}

Akar kuning stems are washed using clean running water, then reduced in size using appropriate equipment such as a knife to form a sharp horn. The haxel is then dried under the morning sun until it dries. The dried haxel is smoothed using a blender until it is smooth enough but not until it becomes a fine powder.

\section{Simplicia Extraction}

The $5 \mathrm{~kg}$ simplicia extracted using the solvent used was ethanol 96\% pro analysis which was added to soak all the simplicia. The maceration vessel is then closed and left to stand for 24 hours with stirring occasionally. The replacement of the extraction solvent is done three times using the same simplicia until the extract obtained is clear. The maceration solvents that have been collected are then put together and filtered and then evaporated using a rotary evaporator at $40^{\circ} \mathrm{C}$ until a thick extract from simplicia is obtained. The concentrated extract was then weighed to determine the yield of the extract.

\section{Antioxidant Test with DPPH Method}

Control solution using DPPH solution concentration of $0.4 \mathrm{mM}$ by dissolving $4 \mathrm{mg}$ of DPPH powder in methanol p.a. on a $25 \mathrm{~mL}$ volumetric flask.Absorbance is read at the maximum theoretical wavelength. The absorbance of the solution is called absorbance control.

The sample solution was made by weighing the extract and dissolved with methanol p.a. and variations in concentration are made.Measurement of sample absorbance: $1 \mathrm{~mL}$ of $0.4 \mathrm{mM}$ DPPH solution was put into a $5 \mathrm{~mL}$ volumetric flask, then added with a sample solution of $4 \mathrm{~mL}$. The solution is allowed to stand for 30 minutes then read the absorbance at the maximum wavelength.

$\%$ Inhibition and $\mathrm{IC}_{50}$ calculation: Made the standard curve equation $y=b x$ $+a$ with the $x$-axis in the form of the concentration of the sample solution and the $y$-axis in the way of\% inhibition of the sample. Furthermore, in the standard curve equation, the variable $y$ is substituted with 50 so that the value of variable $x$ is obtained which is a concentration that can capture $50 \%$ of free radicals for 10 minutes. The $\%$ inhibition is calculated by the formula: 


$$
\% \text { inhibition }=\frac{(A-B)}{A} X 100 \%
$$

$\mathrm{A}=$ Control (DPPH) absorbance

$B=$ Sample or reference absorbance

The $I_{50}$ value is calculated by the formula:

$$
I C 50=\frac{(50-a)}{b}
$$

$\mathrm{a}=$ slope

$\mathrm{b}=$ intercept

\section{RESULTS AND DISCUSSION}

\begin{tabular}{|c|c|c|c|c|c|}
\hline \multirow{2}{*}{ Sample concentration (ppm) } & \multicolumn{4}{|c|}{ Absorbance (̊̊) } & \multirow{2}{*}{ \%Inhibition } \\
\hline & $\mathbf{A}$ & B & A-B & $(A-B) / A$ & \\
\hline 25 & 0.76 & 0.655 & 0.105 & 0.138 & 13.816 \\
\hline 50 & 0.76 & 0.545 & 0.215 & 0.283 & 28.289 \\
\hline 75 & 0.76 & 0.506 & 0.254 & 0.334 & 33.421 \\
\hline 100 & 0.76 & 0.481 & 0.279 & 0.367 & 36.711 \\
\hline
\end{tabular}

Table1. Percentage of sample inhibition

Description: $A=$ Absorbance Control, $B=$ Sample Absorbance

Table 1 shows the results of measurements of absorbance and\% inhibition of akar kuning stem extract. Based on Table 1, it can be seen that from the results of the measurement of antioxidant activity in akar kuning stem extract, it shows that along with the increase in extract concentration, the absorbance value produced decreases. The greater the concentration of the solution, the more antioxidant compounds that become hydrogen or electron donors on DPPH radicals, so that the color of the test solution changes which causes the absorbance produced to be smaller. There
Measurement of antioxidant activity was carried out by the DPPH method. DPPH acts as a free radical that can bind to the $\mathrm{H}$ atom from the sample extract so that it becomes pikrihidrazine, and causes DPPH purple discoloration to be yellow. The antioxidant activity of the sample through the DPPH method can be determined through\% inhibition ${ }^{11}$. The results of \% inhibition of extract samples are shown in table 1: is a proportional relationship between the increase in extract concentration and the $\%$ inhibition value. The greater the concentration of the solution, the higher the $\%$ inhibition value ${ }^{12}$.

Based on the data in Table 1, a sample concentration curve can be made against the $\%$ inhibition as shown in Figure $2 . I C_{50}$ values can be determined through the values of $a$ and $b$ from the linear equation of the concentration curve and\% inhibition. The linear regression equation of the concentration and\% inhibition curves in Figure 2, obtained $y=7.3816 x+9.6053$ and the $R$ value is 0.9423 . The value of $a$ 
$=9.6053$ and $b=0.29526$ is obtained from this equation and from the calculation obtained $\mathrm{IC}_{50}$ value $136.81 \mathrm{ppm}$. This means that the concentration of extract needed to inhibit $50 \%$ of free radicals is
$136.81 \mathrm{ppm}$. As a comparison, ascorbic acid which is the most common antioxidant compound with $\mathrm{IC}_{50}$ of 19.32 ppm (Muharni et al., 2013), while in other studies with IC50 values $24.63 \mathrm{ppm}^{13}$.

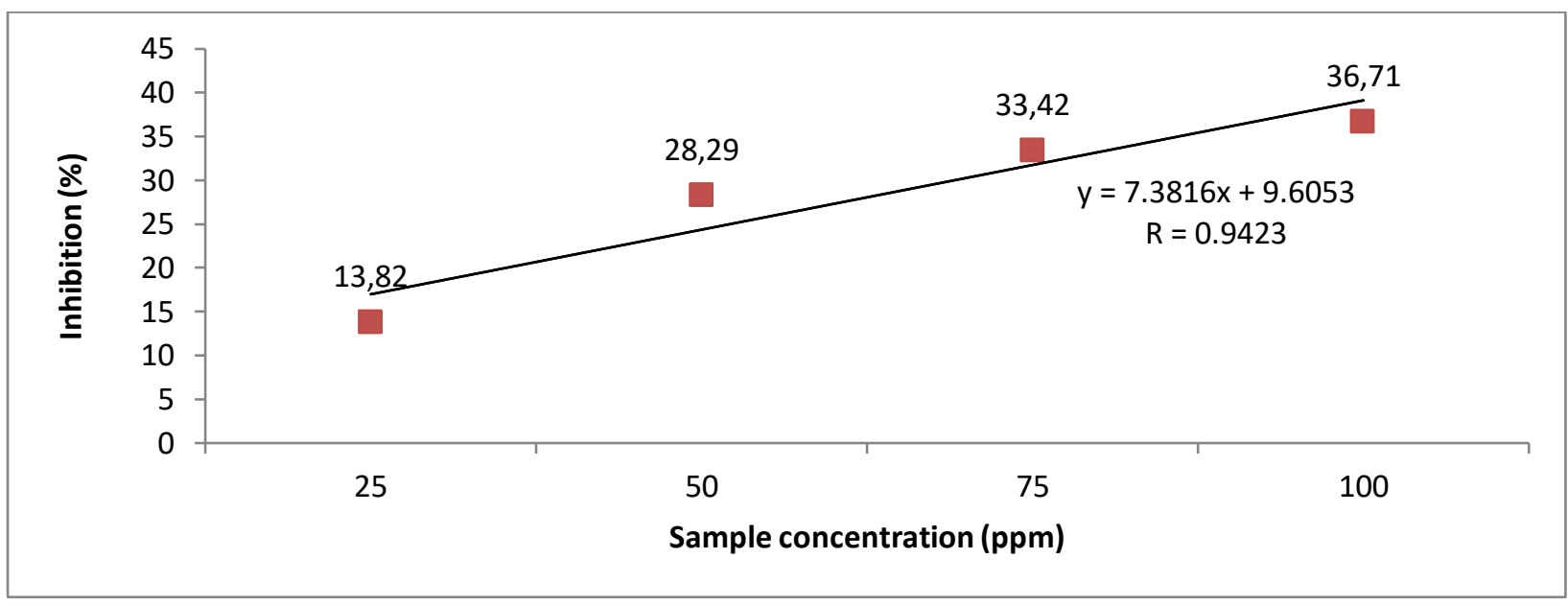

Figure 2. Sample concentration curve with\% inhibition

$\mathrm{IC}_{50}$ value is defined as the amount of concentration of test compounds that can reduce/inhibit free radicals by as much as $50 \%$. The smaller the $\mathrm{IC}_{50}$ value the higher the free radical reduction activity. A substance has antioxidant properties if the $I_{50}$ value is less than 200 ppm. If the $I_{50}$ value obtained ranges from 200-1000 ppm, then the substance is less active but still has the potential as an antioxidant (Molyneux, 2004). A compound is said to be an antioxidant is very strong if the $\mathrm{IC}_{50}$ value is less than $50 \mathrm{ppm}$, strong (50$100)$, moderate (100-150), and weak (151200). The smaller the $I_{50}$ value the higher the antioxidant activity ${ }^{10}$.

\section{CONCLUSION}

Based on the test of antioxidant activity on ethanol extract from akar kuning plant stem $\mathrm{IC}_{50}$ value of $136.81 \mathrm{ppm}$ was obtained. This $\mathrm{IC}_{50}$ value indicates the antioxidant strength of the akar kuning plant stems including moderate. Further research on antioxidant activity in the fraction of akar kuning plant stems needs to be done to determine the composition of the antioxidant compounds in each solvent.

\section{REFERENCES}

1. Setyowati, R., Sudarsono, \& Setyowati, E.P. 2014. The Effect of Water-Soluble Stem Extract "Kayu Kuning" (Arcangelisia flava L. Merr) on The Growth Inhibition of Candida albicans ATCC 10231 and Trichophyton mentagrophytes In Vitro. Biology, Medicine, \& Natural Product Chemistry. Vol. 3 No. $1: 17-22$.

2. Setyowati, Francisca Murti. 2010. Etnofarmakologi dan Pemakaian Tanaman Obat Suku Dayak Tunjung di 
Kalimantan Timur. Media Litbang Kesehatan. Vol. 20 No. 3 : 104-112.

3. Pratama, M.R.F. 2016. Akar kuning (Arcangelisia flava) sebagai inhibitor EGFR: Kajian in silico. Jurnal Pharmagazine. Vol. 3 No. $1: 6-16$.

4. Pratama, M.R.F., Suratno, \& Mulyani, E. 2018. Antibacterial Activity of Akar Kuning (Arcangelisia flava) Secondary Metabolites: Molecular Docking Approach. Asian Journal of Pharmaceutical and Clinical Research. Vol. 11 No. 11 : 447-451.

5. Pratama, M.R.F. 2017. Akar kuning (Arcangelisia flava) as neuraminidase inhibitor: Molecular docking and pharmacophore optimization approach. Advances in Health Science Research. Vol. $6: 502-511$.

6. Sun, Y., Xun, K., Wang, Y., \& Chen, X. 2009. A Systematic Review of The Anticancer Properties of Berberine, a Natural Product from Chinese Herbs. Anti-Cancer Drugs. Vol. 20 : 757 - 769.

7. Widi, R.K. \& Indriati, T. 2007. Penjaringan dan Identifikasi Senyawa Alkaloid dalam Batang Kayu Kuning (Arcangelisia flavaMerr). Jurnal IImu Dasar. Vol. 8 No. 1 : $24-29$.

8. Kasote, D.M., Katyare, S.S., Hedge, M.V., Bae, H. Significance of antioxidant potential of plants and its relevance to therapeutic applications. International Journal of Biological Sciences. Vol. 11 No. $8: 982$ - 991.

9. Dezsi, S., Badarau, A.S., Bischin, C., Vodnar, D.C., Silaghi-Dumitrecu, R., Gheldiu, A.M., Mocan, A., \& Vlase, L. 2015. Antimicrobial and antioxidant activities and phenolic profile of Eucalyptus globulus Labill. and Corymbia ficifolia (F.Muell.) K.D.Hill \&L.A.S. Johnson Leaves. Molecules. Vol. 20 No. $3: 4720-4734$.

10. Agustina, E. Uji aktivitas senyawa antioksidan dari ekstrak daun tiin (Ficus carica Linn) dengan pelarut air, metanol, dan campuran metanol-air. Klorofil. Vol. 1 No. $1: 38-47$.

11. Werdhasari, A. 2014. Peran antioksidan bagi kesehatan. Jurnal Biotek Medisina Indonesia. Vol. 3 No. 2 : 59 - 68.
12. Rohyani, I.S., Aryanti, E., Suripto. Kandungan fitokimia beberapa jenis tumbuhan lokal yang sering dimanfaatkan sebagai bahan baku obat di Pulau Lombok. Prosiding Seminar Nasional Masyarakat Biodiversitas Indonesia. Vol. 1 No. 2 : 388 - 391.

13. Badarinath, A.V., Rao, K.M, Chetty, C.M.S., Ramkanth, S., Rajan, T.V.S., \&Gnanaprakash, K. 2010. A Review on In-vitro Antioxidant Methods: Comparisions, Correlations and Considerations. International Journal of PharmTech Research, 2(2): 1276-1285.

14. Jayaprakasha, G.K., Singh, R.P., \& Sakariah, K.K. 2001. Antioxidant activity of grape seed (Vitis vinifera) ectracts on peroxidation models in vitro. FoodChemistry. Vol. 73 : $285-290$.

15. Jayaprakasha GK, Selvi T, \&Sakariah KK. 2003. Antibacterial and antioxidant activities of grape (Vitis vinifera) seed extracts. FoodResearch International. Vol. 36:117-122.

16. Kedare, S.B. \& Singh, R.P. 2011. Genesis and development of DPPH method of antioxidant assay, Journal of Food Science and Technology, Vol. 48 No. $4: 412-422$.

17. Irnawati, I., Purba, M., Mujadilah, R., \&Sarmayani, S. 2017. Penetapan Kadar Vitamin C dan Uji Aktifitas Antioksidan Sari Buah Songi (Dillenia serrata Thunb.) terhadap Radikal DPPH (Diphenylpicrylhydrazyl). Pharmacon, Vol. 6 No. 2: 40-44.

18. Molyneux, P. 2004. The use of the stable free radical diphenylpicrylhydrazyl (DPPH) for estimating antioxidant activity. Songklanakarin Journalof Science and Technology, 26(2) : 211-219.

19. Muharni, M., Elfita, E., \&Amanda, A. 2013. Aktivitas Antioksidan Senyawa (+) Morelloflavon dari Kulit Batang Tumbuhan Gamboge (Garcinia xanthochymus). Prosiding Semirata FMIPA Universitas Lampung, Lampung. 265-268. 